\title{
The clinical utility of the Kopitnik arteriovenous malformation microclip during STA-MCA bypass surgery
}

\author{
Sung Pil Joo • Tae Sun Kim • Bo Ra Seo • Jung Kil Lee • \\ Jae Hyoo Kim • Soo Han Kim • Joon Tae Kim • \\ Man Seok Park • Ki Hyun Cho
}

Received: 11 December 2008 / Accepted: 29 April 2009/Published online: 26 May 2009

(C) The Author(s) 2009. This article is published with open access at Springerlink.com

\begin{abstract}
Purpose Yasagil temporary clips have been widely used in extracranial-intracranial (EC-IC) arterial bypass surgery. However, the extremely delicate vessels involved often require the application of finer clips. We report on the use of the Kopitnik arteriovenous malformation (AVM) microclip system for superficial temporal artery-middle cerebral artery (STA-MCA) bypass.

Methods Kopitnik AVM microclips are new mechanical devices that are used during AVM surgery. They exert a predefined closing force of 50-70 g, and also feature a special, pyramid-shaped structure stamped on inner surfaces of the blades. These characteristics avoid vascular intimal injury and provide a secure grip. We prospectively studied their use in 15 patients requiring STA-MCA anastomosis.

Results Clinical results were excellent and there were no new ischemic events during 6-months' follow-up.

Conclusions Kopitnik AVM microclips have several advantages; they have small and variously sized clip blades $(2,3$, 4 and $5 \mathrm{~mm}$ ), and the small clip head allows the operator an excellent view of the pathology and clip status. The Kopitnik AVM microclip appears to be clinically effective and safe for EC-IC bypass surgery, especially when smaller vessels are involved.
\end{abstract}

S. P. Joo • T. S. Kim $(\bowtie) \cdot$ B. R. Seo · J. K. Lee ·J. H. Kim $•$

S. H. Kim

Department of Neurosurgery,

Chonnam National University Hospital and Medical School,

8 HakDong, Dong-Gu,

Gwangju 501-757, Republic of Korea

e-mail: taesun1963@yahoo.co.kr

J. T. Kim $\cdot$ M. S. Park $\cdot$ K. H. Cho

Department of Neurology,

Chonnam National University Hospital and Medical School,

Gwangju, Korea
Keywords Microvascular anastomosis · Microclip · STA-MCA bypass

\section{Introduction}

A large variety of extracranial-intracranial (EC-IC) bypasses are available, such as the standard superficial temporal artery-middle cerebral artery (STA-MCA) bypass, radial artery intermediate-flow bypass, and saphenous vein high flow bypass. The choice depends on the pathological condition and the haemodynamic demands of flow through the bypass. Of these techniques, STA-MCA bypass is effective at improving cerebral perfusion in selected patients with refractory cerebral ischaemia or ischaemic moyamoya disease [3]. The Kopitnik arteriovenous malformation (AVM) microclip (Aesculap, Tuttlingen, Germany) is a newly developed self-closing clip device that has been used in AVM surgery (Fig. 1). The present study was designed to evaluate the clinical usefulness and safety of the Kopitnik AVM microclip for STA-MCA anastomosis and to examine the qualities of the anastomoses created.

\section{Patients and methods}

Patient population

Between March and September 2006, 15 patients (12 male and three female patients) were enrolled in this study at Chonnam National University Hospital and Medical School. They had a mean age of 45.2 years, range 1367 years. The characteristics of patients and surgical techniques that were used are summarized in Table 1. The 


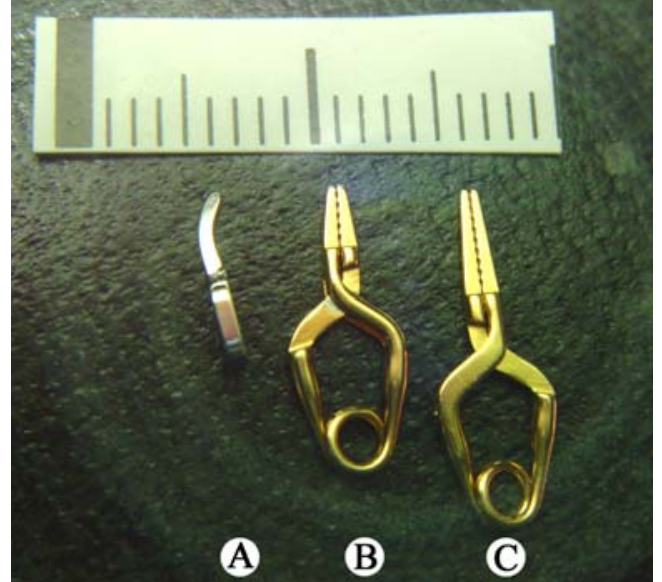

Fig. 1 Photograph of the types of clip usually used during extracranial intracranial arterial bypass. a Kopitnik AVM microclip, b Yasargil temporary miniclip, c Yasargil temporary clip. Kopitnik AVM microclips have a small head and are available in several clipblade sizes indications for STA-MCA bypass surgery were haemodynamic compromise due to atherosclerotic stenoocclusive cerebrovascular disease in 11 patients, and moyamoya disease in four patients. Bilateral operations were performed in one patient with moyamoya disease. Direct revascularization through a standard STA-MCA bypass (11 operations) was performed in atherosclerotic stenoocclusive cerebrovascular disease patients. In addition, in patients with moyamoya disease, standard STA-MCA bypass (five operations) was supplemented by indirect revascularization via encephalomyosynangiosis (EMS).

\section{Surgical technique}

All patients were operated upon by the same surgeon. In general, when the diameter of the MCA is less than $0.5 \mathrm{~mm}$, direct anastomosis is not recommended. After the donor artery has been approximated to the MCA cortical branch, this branch is occluded proximally using a microclip and an additional microclip distally. An arteriotomy appropriate for the donor vessel diameter is made in the recipient vessel using a microscissors (Fig. 4a), and the

Table 1 Summary of patient characteristics (Rt right, $L t$ left, ICA internal carotid artery, CTA computed tomographic angiography)

\begin{tabular}{|c|c|c|c|c|c|c|c|c|c|}
\hline No & Age & Sex & Symptom & Diagnosis & $\begin{array}{l}\text { Operation } \\
\text { name }\end{array}$ & $\begin{array}{l}\text { Occlusion } \\
\text { time (min) }\end{array}$ & $\begin{array}{l}\text { Intraop. } \\
\text { sonographic } \\
\text { patency }\end{array}$ & $\begin{array}{l}\text { Postop. CTA } \\
\text { patency(7days) }\end{array}$ & $\begin{array}{l}\text { Peioperative } \\
\text { complication }\end{array}$ \\
\hline 1 & 31 & $\mathrm{~F}$ & $\begin{array}{l}\text { Rt. Arm } \\
\text { monoparesis }\end{array}$ & $\begin{array}{l}\text { Lt ICA } \\
\text { stenosis }\end{array}$ & EIAB & 40 & Good & Good & \\
\hline 2 & 52 & M & $\begin{array}{l}\text { Lt. } \\
\text { hemiparesis }\end{array}$ & $\begin{array}{l}\text { Rt MCA total } \\
\text { occlusion }\end{array}$ & EIAB & 32 & Good & Good & $\begin{array}{l}\text { Subdural } \\
\text { hygroma }\end{array}$ \\
\hline 3 & 46 & M & $\begin{array}{l}\text { Rt. } \\
\text { hemiparesis }\end{array}$ & $\begin{array}{l}\text { Lt ICA total } \\
\text { occlusion }\end{array}$ & EIAB & 31 & Good & Good & \\
\hline 4 & 38 & M & $\begin{array}{l}\text { Lt. } \\
\text { hemiparesis }\end{array}$ & $\begin{array}{l}\text { Rt ICA total } \\
\text { occlusion }\end{array}$ & EIAB & 40 & Good & Good & \\
\hline 5 & 46 & M & $\begin{array}{l}\text { Lt. } \\
\text { hemiparesis }\end{array}$ & $\begin{array}{l}\text { Rt ICA total } \\
\text { occlusion }\end{array}$ & EIAB & 38 & Good & Good & $\begin{array}{l}\text { Chornic subdural } \\
\text { hemorrahge }\end{array}$ \\
\hline 6 & 31 & $\mathrm{~F}$ & $\begin{array}{l}\text { Rt. } \\
\text { hemiparesis }\end{array}$ & $\begin{array}{l}\text { Moyamoya } \\
\text { disease }\end{array}$ & EIAB + EMS & 36 & Good & Good & \\
\hline 7 & 47 & M & Dizziness & $\begin{array}{l}\text { Rt MCA total } \\
\text { occlusion }\end{array}$ & EIAB & 32 & Good & Good & \\
\hline 8 & 51 & M & $\begin{array}{l}\text { Rt. } \\
\text { hemiparesis }\end{array}$ & $\begin{array}{l}\text { Lt MCA } \\
\text { stenosis }\end{array}$ & EIAB & 36 & Good & Good & \\
\hline 9 & 67 & M & $\begin{array}{l}\text { Rt. } \\
\text { hemiparesis }\end{array}$ & $\begin{array}{c}\text { Moyamoya } \\
\text { disease }\end{array}$ & $\mathrm{EIAB}+\mathrm{EMS}$ & 38 & Good & Good & \\
\hline 10 & 13 & $\mathrm{~F}$ & $\begin{array}{l}\text { Rt. } \\
\text { hemiparesis }\end{array}$ & $\begin{array}{l}\text { Moyamoya } \\
\text { disease }\end{array}$ & $\begin{array}{l}\text { EIAB + EMS } \\
\text { (bilateral) }\end{array}$ & 40 & Good & Good & \\
\hline 11 & 56 & M & $\begin{array}{l}\text { Rt. } \\
\text { hemiparesis }\end{array}$ & $\begin{array}{l}\text { Lt ICA } \\
\text { occlusion }\end{array}$ & EIAB & 32 & Good & Good & \\
\hline 12 & 61 & M & $\begin{array}{l}\text { Lt. } \\
\text { hemiparesis }\end{array}$ & $\begin{array}{l}\text { Rt. ICA } \\
\text { occlusion }\end{array}$ & EIAB & 38 & Good & Good & \\
\hline 13 & 63 & M & $\begin{array}{l}\text { Rt. } \\
\text { hemiparesis }\end{array}$ & $\begin{array}{c}\text { Both ICA } \\
\text { stenosis }\end{array}$ & EIAB & 36 & Good & Good & \\
\hline 14 & 45 & M & Seizure & $\begin{array}{l}\text { Moyamoya } \\
\text { disease }\end{array}$ & $\mathrm{EIAB}+\mathrm{EMS}$ & 30 & Good & Good & \\
\hline 15 & 63 & M & $\begin{array}{l}\text { Rt. } \\
\text { hemiparesis }\end{array}$ & $\begin{array}{c}\text { Both ICA } \\
\text { stenosis }\end{array}$ & EIAB & 37 & Good & Good & \\
\hline
\end{tabular}


Fig. 2 Intraoperative findings showing a small (approximately $5 \mathrm{~mm}$ ), thin, friable recipient artery. In this circumstance, finer clips are needed, so as to avoid recipient vessel injury

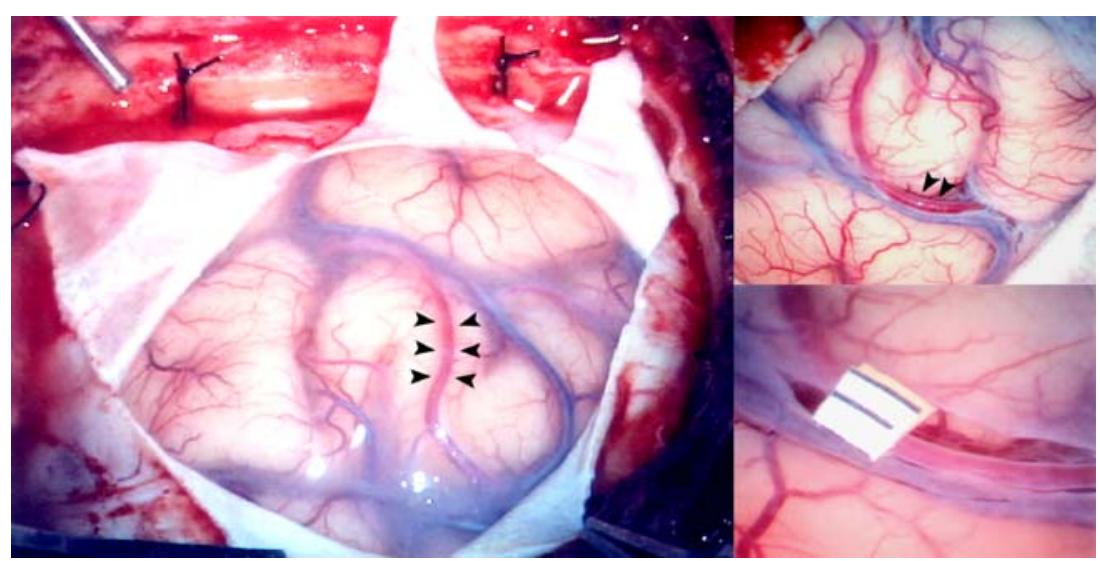

anastomosis completed using interrupted sutures. The recipient vessel clip was removed initially, followed by the donor vessel clip. The duration of cross-clamping of the MCA branch was approximately 30-40 min, and the anastomoses were assessed by microscopic observation and sonographic micro-Doppler.

Water-tight closure of the dura is originally impossible because the STA must run through the dural defect, which is covered by temporal muscle. To reduce frequency of subdural hygroma and subcutaneous cerebrospinal fluid
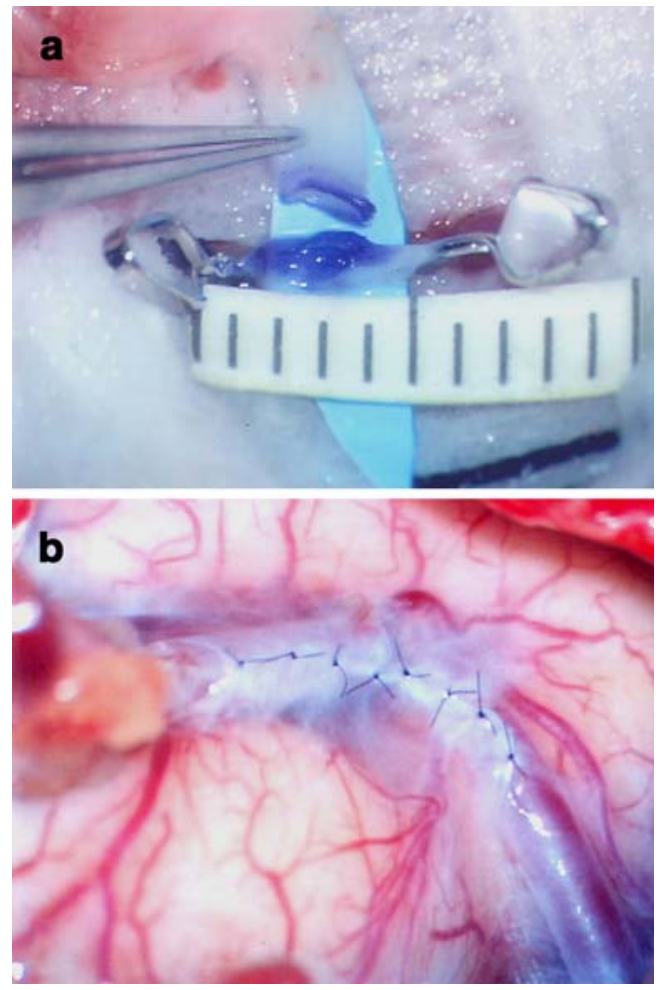

Fig. 3 Intraoperative photographs. a Arteriotomy appropriate for donor vessel diameter being performed, with a short cross-clamp distance so as not to injure the small perforating branch of the cortical artery. $\mathbf{b}$ Arachnoid suturing preventing delayed leakage of CSF
(CSF) collection, we made only a minimal opening of the arachnoid membrane, and this was followed by suturing the arachnoid membrane after STA-MCA bypass using a 10-0 nylon suture (Ethicon, Somerville, N.J.) to prevent CSF leakage (Fig. 4b) in last four patients.

Follow-up

Oral aspirin (100 mg daily) was started for all patients on the second postoperatively day. Postoperative computed tomographic angiography (CTA) was performed at 7 days postoperatively to assess the STA-MCA anastomosis in each case. An experienced neuroradiologist and neurosurgeon independently assessed the patencies of the bypass.

\section{Results}

Sixteen conventional STA-MCA anastomoses, including five indirect revascularizations were performed in the 15 patients. A summary of patient profiles is provided in Table 1. One patient with moyamoya disease underwent a bilateral operation. A standard interrupted technique using 10-0 nylon sutures was used and 12 stitches were used for the bypass. The average time required for anastomosis was $30 \mathrm{~min}$ when 12 sutures were required (two stay sutures and ten interrupted sutures). Satisfactory anastomosis was achieved, even in patients with small or friable recipient vessels, recipient artery flow appeared to be increased in each patient after anastomosis. Transient ischaemic attacks (TIAs) ceased after operation and showed excellent bypass patency in each patient. A complication occurred in two patients; a subdural hygroma without mass effect and a chronic subdural hematoma which were appropriately treated using burr hole and drainage therapy. The Kopitnik microclip system had shortcomings: (1) closure force was reduced suddenly when clips were opened wide or applied several times; thus, they are not reusable; (2) the clips are expensive; (3) they can not be used in high-flow bypass surgery. 
Fig. 4 Photograph of the Kopitnik clip and the inner surface of its blade. a Yasargil temporary clip, b Kopitnik AVM microclip. The Kopitnik AVM microclip features a smoother groove on its inner blade surface than the Yasargil temporary clip

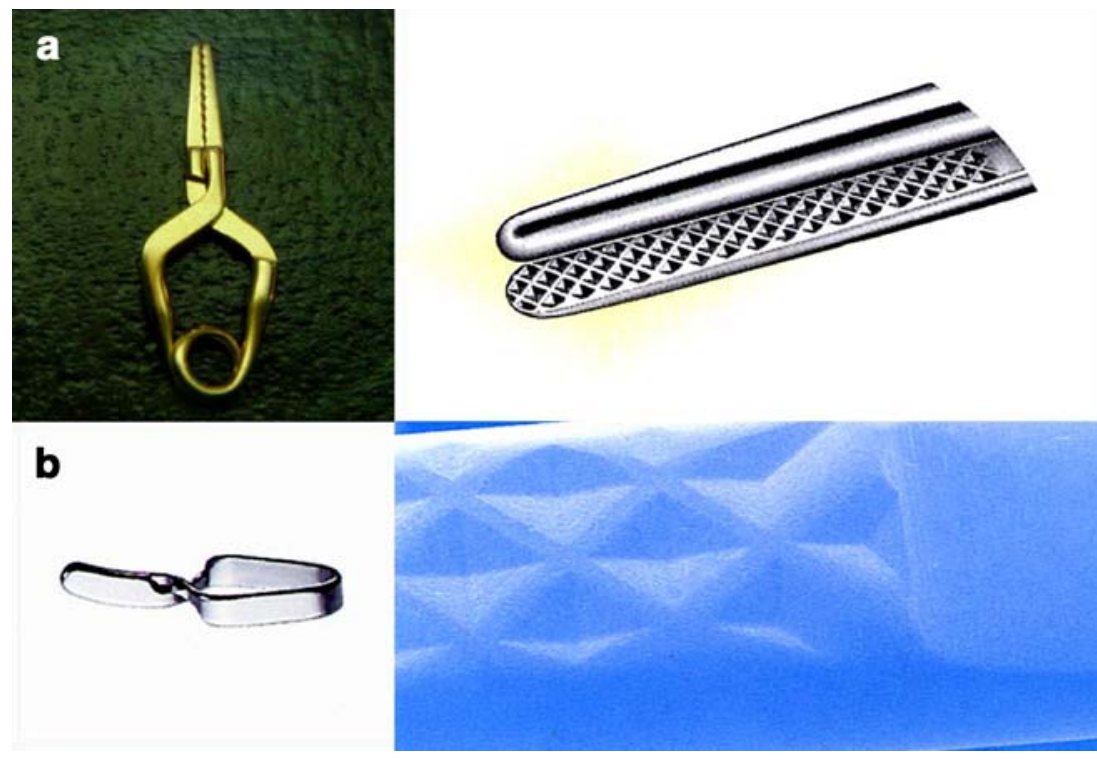

\section{Discussion}

The development of microsuture materials and surgical optical magnification has introduced new surgical possibilities [2] to treat ischaemic brain diseases [9, 15]. Although a range of surgical techniques can be used for STA-MCA bypass, e.g. microsuture-tying forceps with attached scissors [4], double insurance bypass [6], partial lateral clipping [1], minimally occlusive microvascular anastomosis [5], excimer laser-assisted non-occlusive anastomosis(ELANA) $[11,12]$, and the microanastomotic system [7], each has unique advantages and shortcomings.

Krishnan et al. [5] described a new technique for performing microvascular anastomoses with persistent perfusion using a temporary intraluminal microshunt. The anastomosis can be performed via a minimally occlusive technique that guarantees continuous blood flow and prevents cerebral ischemia even if the suturing of the anastomosis itself takes some time. Insertion of the microcatheter into the artery lumen may cause endothelial injury and thromboembolism. The ELANA techniquedeveloped, clinically applied, and refined by Streefkerk et al. [10-13] - may find wide application because of its uncomplicated approach to solving the problem of brain ischemia induced by temporary clipping during vascular anastomosis. However, this technique is only suitable for large calibre vessels $(>3 \mathrm{~mm})$ and carries doubt about the precise patten of intima-to-intima alignment of vessels.

Yasagil temporary clips have been widely used in ECIC bypass surgery. Their closing force lies in the range 70-90 g. In animal experiments, at least $80 \mathrm{~g}$ was found to be required to close an artery, and more than $120 \mathrm{~g}$ damaged the arterial wall [14]. Ooka et al. [8] reported that both the Sugita and Yasargil temporary clips show a marked increase in closing force toward their bases (144 and $162 \mathrm{~g}$, respectively), strong enough to damage an arterial wall.

In our experience, direct anastomosis is difficult in children with moyamoya diseases because the STA and MCA are very small and thin, and their walls are extremely fragile and vulnerable. Such extremely delicate vessels, so as not to injure recipient vessels, often require the application of finer clips than conventional Yasargil temporary clips. We used a special AVM microclip system for STA-MCA bypass (Fig. 2). The clips exert a pre-defined closing force of 50-70 g and feature a special, pyramidshaped structure stamped on the inner surface of the blades (Fig. 3). This allows tissue to sink between these pyramid shapes, doubling the tissue contact surface, and ensuring a secure grip of the vessel. These characteristics avoid injury of vascular intima and reduce the possibility of delayed thromboembolism. AVM microclips have a small clip blade and head, and their characteristics allow minimization of arachnoid dissection to about a 5-mm cross-clamp distance and thus reduce injury of minute arterial branches from the MCA (Fig. 4). In addition, the small clip head allows the operator an excellent view of the pathology and clip status. In the present study, all clips worked as intended in all patients, and no failure to release or inadequate closure was encountered.

\section{Conclusion}

It was feasible to use Kopitnik self-closing microclips for STA-MCA anastomosis, especially with small-vessel disease; they did not adversely affect graft patency or quality and after 6 months of follow-up appeared effective and 
safe. Further study of a larger number of patients with longer follow-up is warranted.

Open Access This article is distributed under the terms of the Creative Commons Attribution Noncommercial License which permits any noncommercial use, distribution, and reproduction in any medium, provided the original author(s) and source are credited.

\section{References}

1. Akay KM (2003) End-to-side anastomoses in small arteries with partial lateral clipping. An experimental study. Minim Invasive Neurosurg 46:22-28. doi:10.1055/s-2003-37965

2. Buncke HJ Jr (2000) Microvascular hand surgery-transplants and replants-over the past 25 years. J Hand Surg [Am] 25:415-428. doi:10.1053/jhsu.2000.4167

3. Ishikawa T, Houkin K, Kamiyama H, Abe H (1997) Effects of surgical revascularization on outcome of patients with pediatric moyamoya disease. Stroke 28:1170-1173

4. Kohno M, Segawa H, Nakatomi H, Sano K, Akitaya T, Takahashi $\mathrm{T}$ (2003) Microsuture-tying forceps with attached scissors for bypass surgery. Surg Neurol 60:463-466. doi:10.1016/S00903019(03)00432-4

5. Krishnan KG, Tsirekidze P, Pinzer T, Schackert G (2005) A novel minimally occlusive microvascular anastomosis technique using a temporary intraluminal shunt: a prospective technique to minimize brain ischemia time during superficial temporal artery-to-middle cerebral artery bypass. Neurosurgery 57:191-198. doi:10.1227/01. NEU.0000163605.15414.55 discussion 191-198

6. Ishikawa T, Kamiyama H, Kobayashi N, Tanikawa R, Takizawa K, Kazumata K (2005) Experience from "double-insurance bypass." Surgical results and additional techniques to achieve complex aneurysm surgery in a safer manner. Surg Neurol 63:485-490 discussion 490
7. Newell DW, Dailey AT, Skirboll SL (1998) Intracranial vascular anastomosis using the microanastomotic system. Technical note. J Neurosurg 89:676-681

8. Ooka K, Shibuya M, Suzuki Y (1997) A comparative study of intracranial aneurysm clips: closing and opening forces and physical endurance. Neurosurgery 40:318-323. doi:10.1097/ 00006123-199702000-00016

9. Sakalas R, Young HF, Becker DP (1978) Microsurgical cerebral revascularization for the treatment of stroke. Va Med 105:300-304

10. Streefkerk HJ, Bremmer JP, Tulleken CA (2005) The ELANA technique: high flow revascularization of the brain. Acta Neurochir Suppl (Wien) 94:143-148. doi:10.1007/3-21127911-3_23

11. Streefkerk HJ, Bremmer JP, van Weelden M, van Dijk RR, de Winter E, Beck RJ, Tulleken CA (2006) The excimer laserassisted nonocclusive anastomosis practice model: development and application of a tool for practicing microvascular anastomosis techniques. Neurosurgery 58:ONS148-ONS156. doi:10.1227/01. NEU.0000193540.03756.BD discussion ONS148-156

12. Streefkerk HJ, Kleinveld S, Koedam EL, Bulder MM, Meelduk HD, Verdaasdonk RM, Beck RJ, van der Zwan B, Tulleken CA (2005) Long-term reendothelialization of excimer laser-assisted nonocclusive anastomoses compared with conventionally sutured anastomoses in pigs. J Neurosurg 103:328-336

13. Streefkerk HJ, Wolfs JF, Sorteberg W, Sorteberg AG, Tulleken CA (2004) The ELANA technique: constructing a high flow bypass using a non-occlusive anastomosis on the ICA and a conventional anastomosis on the SCA in the treatment of a fusiform giant basilar trunk aneurysm. Acta Neurochir (Wien) 146:1009-1019. doi:10.1007/s00701-004-0296-2 discussion 1019

14. Sugita K, Hirota T, Iguchi I, Mizutani T (1976) Comparative study of the pressure of various aneurysm clips. J Neurosurg 44:723-727

15. Tanahashi N, Meyer JS, Rogers RL, Kitagawa Y, Mortel KF, Kandula P, Levinthal R, Rose J (1985) Long-term assessment of cerebral perfusion following STA-MCA by-pass in patients. Stroke 16:85-91 